\title{
Review Article \\ Rossomyrmex, the Slave-Maker Ants from the Arid Steppe Environments
}

\author{
F. Ruano, ${ }^{1}$ O. Sanllorente, ${ }^{1,2}$ A. Lenoir, ${ }^{3}$ and A. Tinaut ${ }^{1}$ \\ ${ }^{1}$ Departamento de Zoología, Universidad de Granada, 18071 Granada, Spain \\ ${ }^{2}$ Departamento de Biología Experimental, Facultad de Ciencias Experimentales, Universidad de Jaén, \\ Campus Las Lagunillas s/n, 23071 Jaén, Spain \\ ${ }^{3}$ Institut de Recherche sur la Biologie de l'Insecte, IRBI-UMR CNRS 7261, Faculté des Sciences et Techniques, \\ Université François Rabelais, 37200 Tours, France
}

Correspondence should be addressed to F. Ruano; fruano@ugr.es

Received 8 March 2013; Accepted 9 May 2013

Academic Editor: David P. Hughes

Copyright (C) 2013 F. Ruano et al. This is an open access article distributed under the Creative Commons Attribution License, which permits unrestricted use, distribution, and reproduction in any medium, provided the original work is properly cited.

\begin{abstract}
The host-parasite genera Proformica-Rossomyrmex present four pairs of species with a very wide range of distribution from China to Southeastern Spain, from huge extended plains to the top of high mountains. Here we review (1) the published data on these pairs in comparison to other slave-makers; (2) the different dispersal ability in hosts and parasites inferred from genetics (chance of migration conditions the evolutionary potential of the species); (3) the evolutionary potential of host and parasite determining the coevolutionary process in each host-parasite system that we treat to define using cuticular chemical data. We find a lower evolutionary potential in parasites than in hosts in fragmented populations, where selective pressures give advantage to a limited female parasite migration due to uncertainty of locating a host nest. A similar evolutionary potential is detected for hosts and parasites when the finding of host nests is likely (i.e., in continuous and extended populations). Moreover, some level of local adaptation at $\mathrm{CHC}$ profiles between host and parasite exists independently of the kind of geographic distribution and the ability of dispersal of the different populations. Similarity at $\mathrm{CHC}$ profiles appears to be a trait imposed by natural selection for the interaction between hosts and slave-makers.
\end{abstract}

\section{Introduction}

Slave-making ants are a type of permanent social parasites (thus depending on enslaved hosts ants throughout their whole live) whose newly mated queens need to usurp a host nest in order to initiate a new parasite colony. Then the host brood will turn into slaves working for the parasite species while parasite workers only concentrate on replenishing the labour force from neighboring host nests, a process called slave raiding (see reviews [1-4]).

The slave-maker style of life imposes selection pressures to both parts, as frequent slave raids strongly affect host populations and on the other hand, invading a host nest by parasite queens is determinant for their survival (see $[2,5,6])$. In this sense the study of host-parasite systems allows the study of coevolutionary strategies.

Within the subfamily Formicinae only two genera fit the previous definition of slave-makers: Polyergus and
Rossomyrmex [5-7]. The species of the Formica sanguinea group are facultative slave-makers $[8,9]$. Thus, in relation with the obligate slave-maker genera most of the published studies are focused on Polyergus biology (e.g., [10-15]) whereas the genus Rossomyrmex has received little attention, probably due to its geographic distribution and biology. However, this genus presents unique raiding $[7,16]$ and mating [17] behaviors in ants (for a comparison with other Formicini genera see Table 1) that make its study very interesting from an evolutionary point of view.

To date there are four species of the slave-making ants Rossomyrmex and, to our knowledge, each parasite species has a single host from the genus Proformica, thus forming unique coevolving pairs: $R$. proformicarum Arnoldi 1928P. epinotalis Kuznetsov-Ugamsky 1927 from Caucasus and Volga plains (Russia), R. quandratinodum Xia and Zeng 1995-P. sp. (Kazakhstan and China), and $R$. anatolicus Tinaut 2007-P. korbi Emery 1909 (from Turkey). These Asian 
TABLE 1: Some traits about the biology of the three Formicini slave-making genera.

\begin{tabular}{|c|c|c|c|}
\hline & Rossomyrmex & Polyergus & F. sanguinea group \\
\hline Parasitism & Obligate & Obligate & Facultative \\
\hline Recruitment & Transport of workers to the target nest & Group recruitment & Group recruitment \\
\hline Raiding & $\begin{array}{l}\text { (i) No use of semiochemicals } \\
\text { (ii) Rare fights } \\
\text { (iii) Host-nest exploitation extended in } \\
\text { time ( } 2 \text { days) } \\
\text { (iv) Not reraiding on the same nest } \\
\text { (v) Average } 2 \text { raids/year } \\
\text { (vi) Slaves do not participate }\end{array}$ & $\begin{array}{l}\text { (i) Alarm semiochemicals } \\
\text { (ii) Some fights } \\
\text { (iii) Intense and quick host-nest } \\
\text { exploitation }(<1 \mathrm{~h}) \\
\text { (iv) Reraiding on the same nest } \\
\text { (v) Maximum } 50 \text { raids/year } \\
\text { (vi) Slaves do not participate }\end{array}$ & $\begin{array}{l}\text { (i) No use of semiochemicals } \\
\text { (ii) Intense fights } \\
\text { (iii) Intense host-nest } \\
\text { exploitation (several hours) } \\
\text { (iv) Reraiding on the same nest } \\
\text { (v) More than } 26 \text { raids/year } \\
\text { (vi) Slaves participate }\end{array}$ \\
\hline Mating & $\begin{array}{l}\text { (i) Sexual calling } \\
\text { (ii) Return to the mother nest after } \\
\text { mating } \\
\text { (iii) Polygamous male } \\
\text { (iv) Single female mating: monandry } \\
\text { (with some exceptions) }\end{array}$ & $\begin{array}{l}\text { (i) Mating on the ground or even during } \\
\text { raids } \\
\text { (ii) Variable. Return to the mother nest } \\
\text { after mating, fly away } \\
\text { (iii)? } \\
\text { (iv) Single female mating: monandry } \\
\text { (with some exceptions) }\end{array}$ & $\begin{array}{l}\text { (i) Nuptial flight, intranidal } \\
\text { mating } \\
\text { (ii) Return to the own or } \\
\text { conspecific nest after mating } \\
\text { (iii)? } \\
\text { (iv) Multiple mating: polyandry }\end{array}$ \\
\hline Sex allocation & Female biased & $?$ & Female biased \\
\hline Foundation & $\begin{array}{l}\text { (i) Usurpation } \\
\text { (ii) New queen enters a host nest alone } \\
\text { (iii) repellent substance from Dufour's } \\
\text { gland (Tetradecanal) }\end{array}$ & $\begin{array}{l}\text { (i) Usurpation } \\
\text { (ii) New queen enters a host nest during a } \\
\text { raid } \\
\text { (iii) Appeasement substance from } \\
\text { Dufour's gland (decyl butanoate) }\end{array}$ & $\begin{array}{l}\text { (i) Variable (adoption, } \\
\text { usurpation) } \\
\text { (ii) New queen enters a host nest } \\
\text { during a raid } \\
\text { (iii) Substances from Dufour's } \\
\text { gland of unknown effect (n-decyl } \\
\text { acetates) }\end{array}$ \\
\hline
\end{tabular}

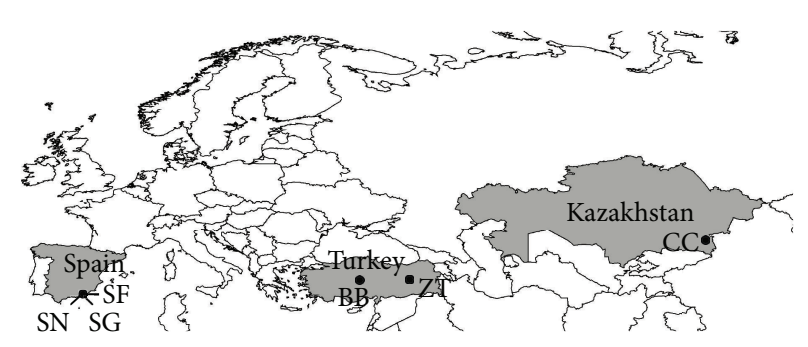

Figure 1: Distribution of the studied species: Spain (with three Rossomyrmex minuchae populations: $\mathrm{SN}=$ Sierra Nevada, $\mathrm{SG}=$ Sierra de Gador, and SF = Sierra de Filabres), Turkey (with two $R$. anatolicus populations: $\mathrm{BB}=$ Belembaçi Beli, $\mathrm{ZT}=$ Ziyaret Tepesi), and Kazakhstan (one R. quandratinodum population: $\mathrm{CC}=$ Charyn Canyon) (from [20]).

parasite-host pairs live mostly in extended plains whereas the Spanish pair R. minuchae Tinaut 1981-P. longiseta Collingwood 1978 inhabits the top of three high mountains in southern Spain (Figure 1). Despite this apparent difference in habitat (extended plains versus high mountains), the abiotic conditions are quite similar and are consistent with a typical arid steppe $[7,18,19]$. However, the main difference comes from the fact that the Spanish populations are small and are geographically isolated from each other [20].

The most studied pair is $R$. minuchae-P. longiseta, and in the last years we obtained data on Asian R. anatolicus-P. korbi and $R$. quandratinodum-P. sp. pairs. Dispersal ability of hosts and parasites and how this trait conditions the genetics and distribution of the species and its coevolution are principal goals of many of the articles recently published in slavemaking ants.

\section{A Singular Biology}

The reproductive behavior of slave-making ants usually consists in synchronous emergence of sexuals followed by a nuptial flight and the invasion of a host nest [21], but also in some cases females display a mating call around the natal nest to attract males and immediately after mating search for a host nest to usurp (e.g., [2]). However, the reproductive strategy of Rossomyrmex greatly differs from the one described above. Males and females emerge from the natal nest at a different time during the day and males always fly away short after their emergence. Virgin females of Rossomyrmex show a typical mating call behavior near the natal nest but due to the scarce number of nests and that sexuals are not produced every year in all nests, some females remain virgin and cannot produce new nests despite performing sexual calling chorus for several days [17]. When a male arrives at a female-calling nest, he will mate to as many females as possible, being one of the few cases known of polygamous males in ants $[17,22]$, especially when mating occurs out of the nest. In contrast, females are strictly monandrous although there are some reported cases of multiply mated queens [20]. Females recently mated always run to hide in their natal nest after the first copulation and do not seek for subsequent mating [17]. This reproductive behavior seems to be constrained by 
the low production of sexuals, especially males (which gives advantage to female-calling behavior rather than nuptial flights and multiple mating by males).

Newly mated queens search for a host nest to invade and they are unchallenged by host workers and queens thanks to the repellent effect of the Dufour's gland that they have highly inflated before the usurpation. After taking over the host nest by killing the resident queens, the size of this gland decreases [23]. This strategy to invade a host nest contrasts with other extended strategy consisting in newly mated queens embarking in a slave raid with workers, which would facilitate the penetration of the host nest immersed in chaos $[2,3,9]$.

As stated before, parasitized nests need to replenish the host workers periodically and this is achieved by raiding. The normal process is that after finding a new host nest to invade, the parasite worker marks the way to its nest with pheromones and afterwards fellow slave-makers are attracted in few seconds. Then they go quickly to the targeted host nest, attack it, and carry as many larvae and pupae as possible and return to their nest following the same trail marked by the pheromone [14]. Workers of the attacked nest can fight or flee although in Proformica the most common behaviour is flight probably because hosts always lose fights [24]. Interestingly, Rossomyrmex is the only reported slave-maker that exclusively uses adult transport and single recruitment chain instead of pheromones during raids [7, 16, 19], a behavior probably constrained by the arid habitat: raids take place in early summer when soil surface temperature can reach up to $30^{\circ} \mathrm{C}$, a temperature for which pheromones would quickly evaporate $[6,25]$. This condition imposes that Rossomyrmex raids appears as less efficient than those carried out with pheromones; this together with the usually flee behavior of the Proformica hosts [19] permits the survival of several attacked nests [24]. Finally, another important difference in the raiding behavior of Rossomyrmex is that the return to the parasite nest with the robbed brood takes place at the following day of the assault instead of later in the same day [7].

\section{Dispersal Abilities Evidence and Evolutionary Potential Inferred from Genetics}

In the Proformica-Rossomyrmex system, dispersal ability is quite different for host and parasite species. The ant genus Proformica is generally polygynous (multiple queen colonies) with wingless queens that found new nests by budding [26]; therefore they are likely to show restricted dispersal and strong population structure. The genus Rossomyrmex is monogynous (single queen colonies), with both sexes winged and show independent colony founding $[17,27,28]$. In the species studied we can distinguish between $R$. minuchae, living on the top of three different mountains and the Asian species living in continuous plains, without apparent geographical barriers.

Dispersal is a crucial life-history trait determining genetic variability and sometimes the survival of entire populations
[29]. The coevolutionary trajectories of hosts and parasites are mostly affected by the difference in migration [30], so that if the migration rate of the parasite is lower than that of the host, the host is expected to present stronger local adaptation to the parasite than vice versa $[31,32]$. Population genetics theory states that genetic diversity is positively correlated with population size and this, in turn, is reduced as a consequence of the habitat fragmentation [33].

In agreement with this, $R$. anatolicus from Turkey shows higher levels of microsatellite variation than $R$. minuchae but lower population differentiation (even $425 \mathrm{~km}$ distant) than in the Spanish species, whose genetic differences among populations were highly significant [20]. Likewise $R$. anatolicus presents a lack of mitochondrial haplotype variation (for cytochrome oxidase c gene), confirming a continuous distribution of the species in the Turkish extended steppe. In contrast, the Spanish $R$. minuchae populations presented a highly significant population differentiation for this trait, clearly separated in different high mountains, but with very low and nonsignificant within population differences [34]. These results from microsatellites and mitochondrial COI likely reflect a history of long-term fragmentation for $R$. minuchae, compared to a more continuous distribution for R. anatolicus.

On the other hand, relative levels of gene flow and population sizes of hosts and parasites determine their coevolutionary potential and are therefore among the main determinants of the coevolutionary dynamics. Parasites have usually been predicted to have an evolutionary advantage, leading the coevolutionary process $[35,36]$, although in some studies a similar evolutionary potential for hosts and parasites has been described [37], or even lower for parasites than for hosts [38].

In the Spanish R. minuchae-P. longiseta parasite-host system the estimates of gene flow for both species resulted in great differences, being in the host an order of magnitude higher [39]. Therefore there is a good probability that these estimates indicate a higher migration rate for the host species (despite females being wingless) than the parasite, which would be interpreted as to they are more prone for local adaptation due to a higher evolutionary potential than in the parasite, as occurred in other slave-maker ants [38]. The existence of this disequilibrium suggests that natural selection can act favoring low dispersal in slave-making ants living in fragmented habitats. In this case a short range dispersal can be selective for ensuring the possibility of finding a host nest in the same population, with an appropriate density, and in which hosts can be locally adapted to the parasite (more similar CHCs ensuring tolerance) [24]. In fact, adaptation of the parasite to the host is the result of the strength of natural selection and the evolutionary potential of the parasite [35].

In contrast to this result, we did not find significant differences in genetic diversity and population differentiation for $R$. anatolicus with a mean gene diversity of $0.657 \pm 0.07$ (SE) [20], similar to that of its host P. korbi $(0.70 \pm 0.06)$ (unpublished). In the Asian extended plains host and parasite showed a similar dispersal ability and evolutionary potential, as a result of a continuous host distribution not offering obstacles to the spread of the parasite. 


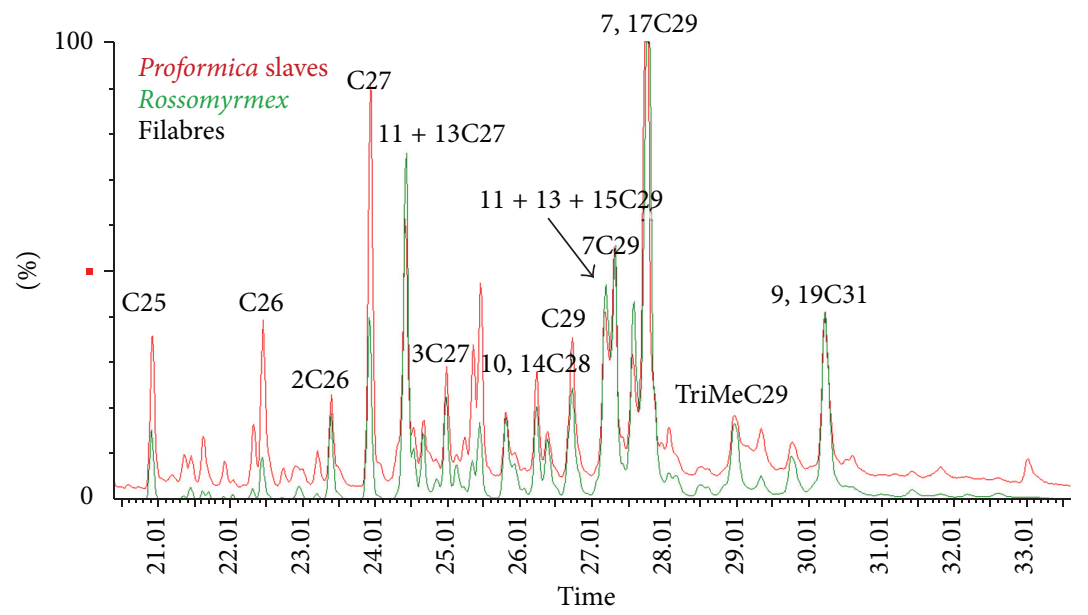

Figure 2: CHCs profiles of $R$. minuchae and P. longiseta (Sierra de Filabres population). The profiles are superposed to show the similarity between the host and parasite with some differences, for example, in alkanes C25, C26, and C27.

\section{Cuticular Hydrocarbons as a Tool to Study Coevolution}

Nestmate recognition is a key trait in social insect organization, which is essential to avoid parasitism, predation, and competition [5]. In this sense, cuticular hydrocarbons (CHCs) have been demonstrated to play a main role in nestmate recognition [40] and usually each ant species has its own chemical profile $[41,42]$. Social parasites such as slavemakers are able to cheat their hosts chemically by actively acquiring or evolving similar cuticular profiles of their hosts (see [43]) in order to favor social integration in the nest and avoid aggression [44]. Hence, chemical distances between $\mathrm{CHC}$ profiles are a useful trait to study local host-parasite coevolution and adaptation, as a measure of recognition ability and potential aggression between host and parasite $[24,39,45,46]$.

$R$. minuchae and its host $P$. longiseta have exactly the same cuticular hydrocarbons, as predicted in a host-parasite acceptance in the same nest. However, small quantitative differences between host and parasite profiles indicate that they are able to recognize each other (Figure 2). Combined chemical and behavioral studies conducted in the $R$. minuchae-P. longiseta system showed that sympatric hosts were chemically closer to the parasites than to allopatric hosts despite being from the same species. This result was also supported by a reduced aggression between sympatric parasites and hosts compared to allopatric hosts [24]. Hosts that better match the chemical profile of the parasite have a higher survival chance during raids. This possibility comes from the fact that slave-makers would not benefit from a less virulent behavior (given that they always win the fights) if host densities are constantly high [30], as it is the case of $P$. longiseta [47]. Contrarily, in other host-parasite systems involving phylogenetically distant species (MaculineaMyrmica species [45]), the coevolutionary outcome for host species is diverging CHCs. For Myrmica hosts, nests that detect the parasite have a differential survival, being clearly advantageous.

It has been proved that the differences between the $\mathrm{CHC}$ profiles of the host and parasite, which may be responsible for the tolerance towards the parasite, varied between the Spanish $P$. longiseta- $R$. minuchae populations, suggesting, at a regional level, a selection mosaic of coevolution [39]. Each host-parasite Spanish population is in a different coevolutionary time, as evidenced by the different $\mathrm{CHC}$ distances (Nei distances, [48]) between parasites and hosts in each population. This situation probably produces different host strategies to minimize the effects of parasitism on fitness: from resistance, in species or populations with more separated host-parasite $\mathrm{CHC}$, to tolerance, in those with closest host-parasite CHC [39].

For the Asian host-parasite systems, different profiles appeared in the various parasite species (Figure 3). As for the chemical congruence between host and parasite, $R$. quandratinodum and $P$. sp. present the highest cuticular distances that would indicate the highest level of hostparasite aggressiveness [34]. This is also supported by the significantly lower proportion of slaves in R. quandratinodum nests compared to the other species (see [49]) and the aggressive behavior observed by the authors in the laboratory. In contrast, $R$. anatolicus and $P$. korbi seem to be the most similar chemically [34] and locally adapted, showing host and parasite with a similar evolutionary potential; therefore this host species should be the least aggressive.

This finding supports that population isolation is not strictly necessary for coevolution meanwhile dispersal may favor local adaptation in broadly distributed species by incorporating genetic variability and more chances to a local adaptation $[5,36,50]$. Nevertheless, some level of local adaptation at $\mathrm{CHC}$ profiles between host and parasite exists independently of the kind of geographic distribution (continuous or fragmented) and the ability of dispersal of the different populations. Similarity at $\mathrm{CHC}$ profiles appears to be 

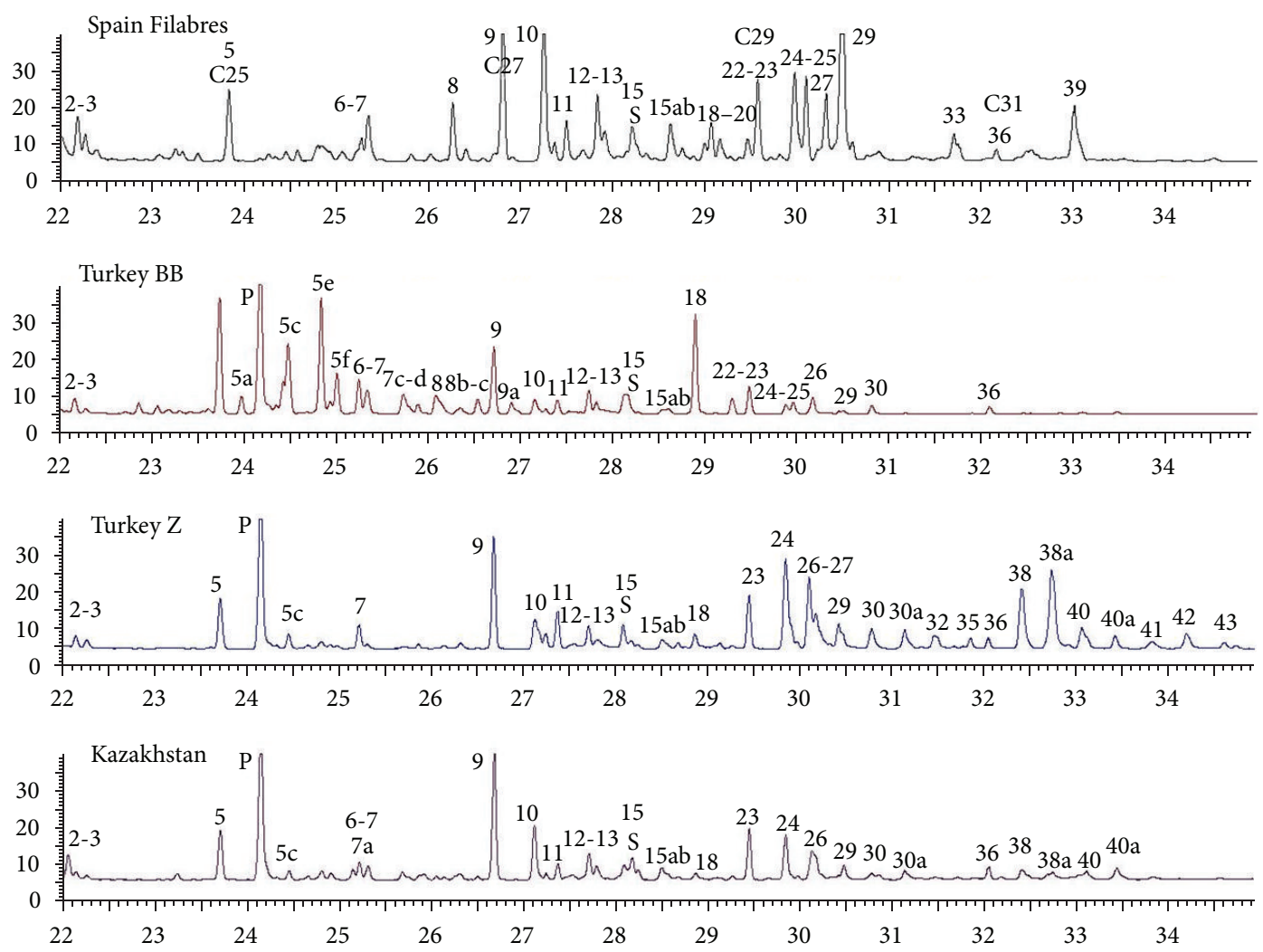

Figure 3: CHCs profiles for $R$. minuchae (Filabres), R. anatolicus (from two different populations Turkey BB = Belembaçi Beli, Turkey Z = Ziyaret Tepesi), and R. quandratinodum (Kazakhstan). Numbers refer to original data in [34] (P and S are pollutants).

a trait imposed by natural selection to the interaction between hosts and slave-makers (and more generally between hosts and parasites), a necessity for the system work.

\section{Future Directions}

A broader sampling for genetic and behavioral data, including more data on R. quandratinodum and R. proformicarum$P$. epinotalis, is required to depict a more general landscape of local adaptation and coevolution in the ProformicaRossomyrmex pairs.

\section{Acknowledgments}

The authors thank Patrizia D'Ettorre for review of data on Polyergus and Formica sanguinea species biology and the commentaries of two anonymous referees that improved considerably the paper.

\section{References}

[1] A. Buschinger, "Evolution of social parasitism in ants," Trends in Ecology and Evolution, vol. 1, no. 6, pp. 155-160, 1986.

[2] H. Topoff, "Slave-making queens," Scientific American, vol. 281, no. 5, pp. 84-90, 1999.

[3] P. D'Ettorre and J. Heinze, "Sociobiology of slave-making ants," Acta Ethologica, vol. 3, no. 2, pp. 67-82, 2001.
[4] A. Buschinger, "Social parasitism among ants: a review (Hymenoptera: Formicidae)," Myrmecological News, vol. 12, pp. 219-235, 2009.

[5] E. O. Wilson, The Insect Societies, Belknap Press, Cambridge, Mass, USA, 1971.

[6] A. Mori and F. Le Moli, "Behavioural plasticity and domestic degeneration in facultative and obligatory slave-making ant species (Hymenoptera, Formicidae)," Monitore Zoologico Italiano, vol. 22, pp. 271-285.

[7] F. Ruano and A. Tinaut, "Raid process, activity pattern and influence of abiotic conditions in the slave-making ant Rossomyrmex minuchae (Hymenoptera, Formicidae) a slavemaker species," Insectes Sociaux, vol. 46, no. 4, pp. 341-347, 1999.

[8] B. H. Hölldobler and E. O. Wilson, The Ants, Springer, Berlin, Germany, 1990.

[9] A. Mori, D. A. Grasso, R. Visicchio, and F. Le Moli, "Comparison of reproductive strategies and raiding behaviour in facultative and obligatory slave-making ants: the case of Formica sanguinea and Polyergus rufescens," Insectes Sociaux, vol. 48, no. 4, pp. 302314, 2001.

[10] M. Talbot, "Slave-raids of the ant Polyergus lucidus Mayr," Psyche, vol. 74, pp. 199-231, 1967.

[11] H. Topoff and L. Greenberg, "Mating behavior of the sociallyparasitic ant, Polyergus breviceps: the role of the mandibular glands," Psyche, vol. 95, pp. 81-88, 1988.

[12] F. Le Moli, D. A. Grasso, A. Mori, and A. Ugolini, "Ecoethological factors affecting the scouting and raiding behaviour of the slave-making ant Polyergus rufescens Latr. (Hymenoptera, Formicidae)," Ethology, vol. 96, no. 4, pp. 289-302, 1994. 
[13] A. Mori, D. A. Grasso, P. D’Etorre, and F. Le Moli, “Specifity in host choice by the slave-making ant Polyergus rufescens Latr. (Hymenoptera, Formicidae)," Ethology, Ecology \& Evolution, vol. 3, pp. 89-93, 1994.

[14] S. Boi, V. Capasso, and D. Morale, "Modeling the aggregative behavior of ants of the species Polyergus rufescens," Nonlinear Analysis: Real World Applications, vol. 1, no. 1, pp. 163-176, 2000.

[15] C. A. Johnson, H. Topoff, R. K. Vander Meer, and B. Lavine, "Do these eggs smell funny to you? An experimental study of egg discrimination by hosts of the social parasite Polyergus breviceps (Hymenoptera: Formicidae)," Behavioral Ecology and Sociobiology, vol. 57, no. 3, pp. 245-255, 2005.

[16] F. Ruano and A. Tinaut, "The assault process of the slavemaking ant Rossomyrmex minuchae (Hymenoptera, Formicidae)," Sociobiology, vol. 43, no. 2, pp. 201-209, 2004.

[17] F. Ruano and A. Tinaut, "Mating behaviour in a slavemaking ant, Rossomyrmex minuchae (Hymenoptera, Formicidae)," Naturwissenschaften, vol. 92, no. 7, pp. 328-331, 2005.

[18] K. V. Arnoldi, "Biologische beobachtungen an der neuen paläarktischen sklavenhalterameise Rossomyrmex froformicarum K. Arn., Nebst einigen bemerkungen über die beförderungsweise der ameisen," Zeitschrift für Morphologie und Ökologie der Tiere, vol. 24, no. 2, pp. 319-326, 1932.

[19] P. I. Marikovsky, "The biology of the ant Rossomyrmex proformicarum K. W. Arnoldi (1928)," Insectes Sociaux, vol. 21, no. 3, pp. 301-308, 1974.

[20] O. Sanllorente, R. L. Hammond, F. Ruano, L. Keller, and A. Tinaut, "Extreme population differentiation in a vulnerable slavemaking ant with a fragmented distribution," Conservation Genetics, vol. 11, no. 5, pp. 1701-1710, 2010.

[21] A. Mori, P. D. 'Ettorre, and F. Le Moli, "Mating and post-mating behaviour of the European amazon ant, Polyergus rufescens (Hymenoptera, Formicidae)," Bolletino Zoologia, vol. 61, pp. 203-206, 1994.

[22] U. Winter and A. Buschinger, "Genetically mediated queen polymorphism and caste determination in the slave-making ant Harpagoxenus sublaevis (Hymenoptera: Formicidae)," Entomologia Generalis, vol. 11, pp. 125-137, 1986.

[23] F. Ruano, A. Hefetz, A. Lenoir, W. Francke, and A. Tinaut, "Dufour's gland secretion as a repellent used during usurpation by the slave-maker ant Rossomyrmex minuchae," Journal of Insect Physiology, vol. 51, no. 10, pp. 1158-1164, 2005.

[24] C. Zamora-Muñoz, F. Ruano, C. Errard, A. Lenoir, A. Hefetz, and A. Tinaut, "Coevolution in the slave-parasite system Proformica longiseta-Rossomyrmex minuchae (Hymenoptera: Formicidae)," Sociobiology, vol. 42, no. 2, pp. 299-317, 2003.

[25] L. van Oudenhove, R. Boulay, A. Lenoir, C. Bernstein, and X. Cerdá, "Substrate temperature constrains recruitment and trail following behavior in ants," Journal of Chemical Ecology, vol. 38, pp. 802-809, 2012.

[26] A. Tinaut and F. Ruano, "Braquipterismo y apterismo en Formícidos. Morfología y biometría en las hembras de especies ibéricas de vida libre (Hymenoptera, Formicidae)," Graellsia, vol. 48, pp. 121-131, 1992.

[27] A. Tinaut, "Rossomyrmex minuchae nov. sp. (Hym. Formicidae) encontrada en Sierra Nevada, España, Boletín de la Asociación española de Entomología, vol. 4, pp. 195-203, 1981.

[28] A. Tinaut, F. Ruano, and I. Fernández-Escudero, "Descripción del macho del género Rossomyrmex Arnoldi, 1928 (Hymenoptera, Formicidae)," Nouvelle Revue d'Entomologie, vol. 4, pp. 347-351, 1994.
[29] J. Clobert, E. Danchin, A. A. Dhondt, and J. D. Nichols, Dispersal, Oxford University Press, New York, NY, USA, 2001.

[30] M. Brandt, J. Heinze, T. Schmitt, and S. Foitzik, "A chemical level in the coevolutionary arms race between an ant social parasite and its hosts," Journal of Evolutionary Biology, vol. 18, no. 3, pp. 576-586, 2005.

[31] S. Gandon, Y. Capowiez, Y. Dubois, Y. Michalakis, and I. Olivieri, "Local adaptation and gene-for-gene coevolution in a metapopulation model," Proceedings of the Royal Society B, vol. 263, no. 1373, pp. 1003-1009, 1996.

[32] S. Gandon, "Local adaptation and the geometry of host-parasite coevolution," Ecology Letters, vol. 5, no. 2, pp. 246-256, 2002.

[33] R. Frankham, J. D. Ballou, and D. A. Briscoe, Introduction to Conservation Genetics, Cambridge University Press, Cambridge, UK, 2002.

[34] O. Sanllorente, P. Lorite, S. Devers, F. Ruano, A. Lenoir, and A. Tinaut, "The spatial distribution does not affect host-parasite coevolution in Rossomyrmex ants," Insectes Sociaux, vol. 59, pp. 361-368, 2012.

[35] S. Gandon and Y. Michalakis, "Local adaptation, evolutionary potential and host-parasite coevolution: interactions between migration, mutation, population size and generation time," Journal of Evolutionary Biology, vol. 15, no. 3, pp. 451-462, 2002.

[36] M. Brandt, B. Fischer-Blass, J. Heinze, and S. Foitzik, "Population structure and the co-evolution between social parasites and their hosts," Molecular Ecology, vol. 16, no. 10, pp. 2063-2078, 2007.

[37] P. S. Pennings, A. Achenbach, and S. Foitzik, "Similar evolutionary potentials in an obligate ant parasite and its two host species," Journal of Evolutionary Biology, vol. 24, no. 4, pp. 871886,2011

[38] S. Foitzik, S. Bauer, S. Laurent, and P. S. Pennings, "Genetic diversity, population structure and sex-biased dispersal in three co-evolving species," Journal of Evolutionary Biology, vol. 22, no. 12, pp. 2470-2480, 2009.

[39] F. Ruano, S. Devers, O. Sanllorente, C. Errard, A. Tinaut, and A. Lenoir, "A geographical mosaic of coevolution in a slave-making host-parasite system," Journal of Evolutionary Biology, vol. 24, no. 5, pp. 1071-1079, 2011.

[40] P. D’Ettorre and A. Lenoir, "Nestmate recognition in ants," in Ant Ecology, L. Lach, C. Parr, and K. Abbott, Eds., pp. 194-209, Oxford University Press, Oxford, UK, 2010.

[41] K. A. Copren, L. J. Nelson, E. L. Vargo, and M. I. Haverty, "Phylogenetic analyses of mtDNA sequences corroborate taxonomic designations based on cuticular hydrocarbons in subterranean termites," Molecular Phylogenetics and Evolution, vol. 35, no. 3, pp. 689-700, 2005.

[42] S. J. Martin, H. Helanterä, and F. P. Drijfhout, "Evolution of species-specific cuticular hydrocarbon patterns in Formica ants," Biological Journal of the Linnean Society, vol. 95, no. 1, pp. 131-140, 2008.

[43] A. Lenoir, P. D’Ettorre, and C. Errard, "Chemical ecology and social parasitism in ants," Annual Review of Entomology, vol. 46, pp. 573-599, 2001.

[44] E. Nowbahari, A. Lenoir, J. L. Clément, C. Lange, A. G. Bagneres, and C. Joulie, "Individual, geographical and experimental variation of cuticular hydrocarbons of the ant Cataglyphis cursor (Hymenoptera: Formicidae): their use in nest and subspecies recognition," Biochemical Systematics and Ecology, vol. 18, no. 1, pp. 63-74, 1990. 
[45] D. R. Nash, T. D. Als, R. Maile, G. R. Jones, and J. J. Boomsma, "A mosaic of chemical coevolution in a large blue butterfly," Science, vol. 319, no. 5859, pp. 88-90, 2008.

[46] L. V. Ugelvig, F. P. Drijfhout, D. J. C. Kronauer, J. J. Boomsma, J. S. Pedersen, and S. Cremer, "The introduction history of invasive garden ants in Europe: integrating genetic, chemical and behavioural approaches," BMC Biology, vol. 6, article 11, 2008.

[47] I. Fernández-Escudero and A. Tinaut, "Factors determining nest distribution in the high-mountain ant Proformica longiseta (Hymenoptera Formicidae)," Ethology Ecology and Evolution, vol. 11, no. 4, pp. 325-338, 1999.

[48] S. Dronnet, C. Lohou, J.-P. Christides, and A.-G. Bagnères, "Cuticular hydrocarbon composition reflects genetic relationship among colonies of the introduced termite Reticulitermes santonensis feytaud," Journal of Chemical Ecology, vol. 32, no. 5, pp. 1027-1042, 2006.

[49] A. Tinaut, F. Ruano, O. Sanllorente, A. Fernández-Zambrano, C. Karaman, and Y. Kaz, "Nest composition and worker relatedness in three slave-making ants of the genus Rossomyrmex Arnoldi and their Proformica Ruzsky hosts (Hymenoptera, Formicidae)," Insect Science, vol. 17, no. 4, pp. 361-368, 2010.

[50] B. Fischer and S. Foitzik, "Local co-adaptation leading to a geographical mosaic of coevolution in a social parasite system," Journal of Evolutionary Biology, vol. 17, no. 5, pp. 1026-1034, 2004. 

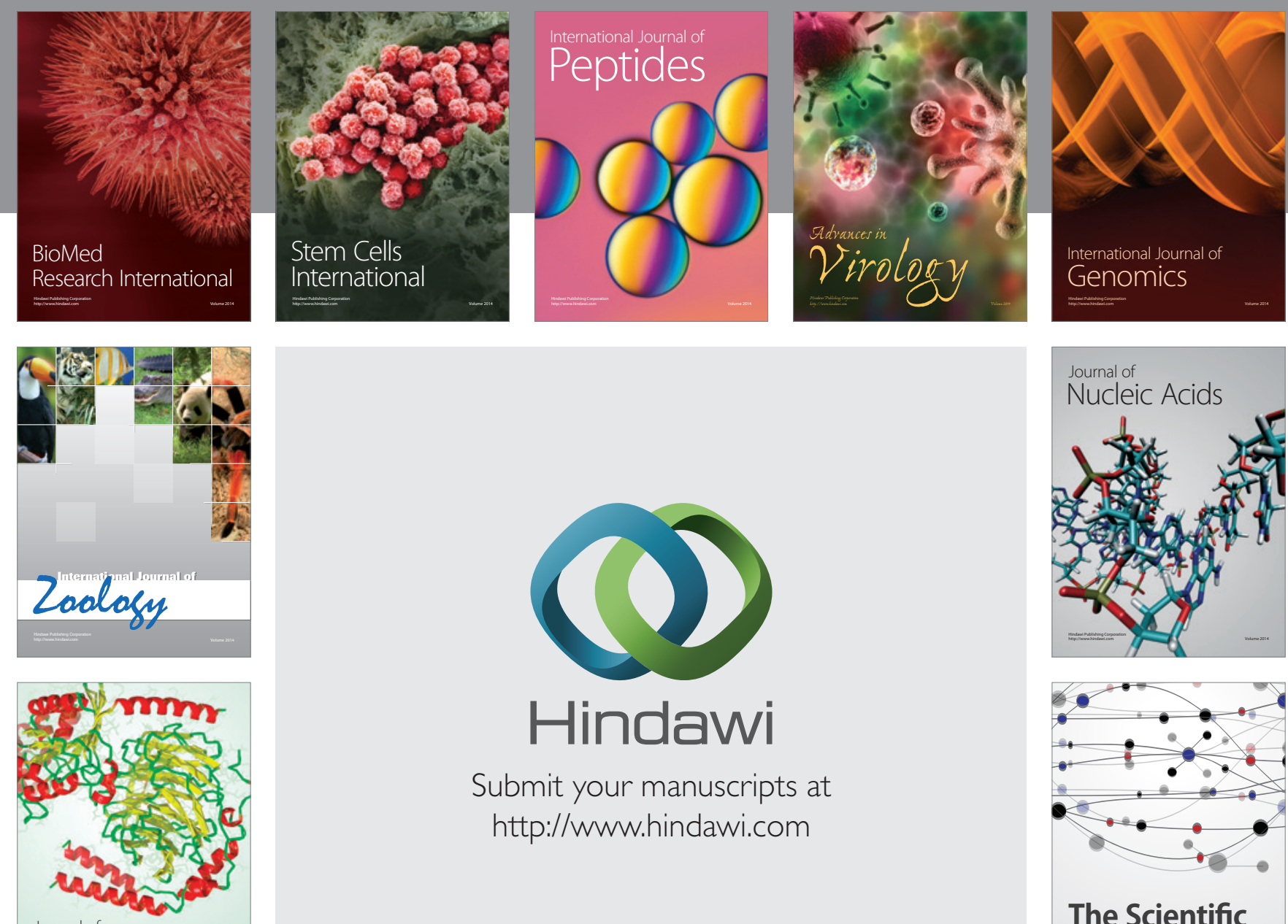

Submit your manuscripts at

http://www.hindawi.com

Journal of
Signal Transduction
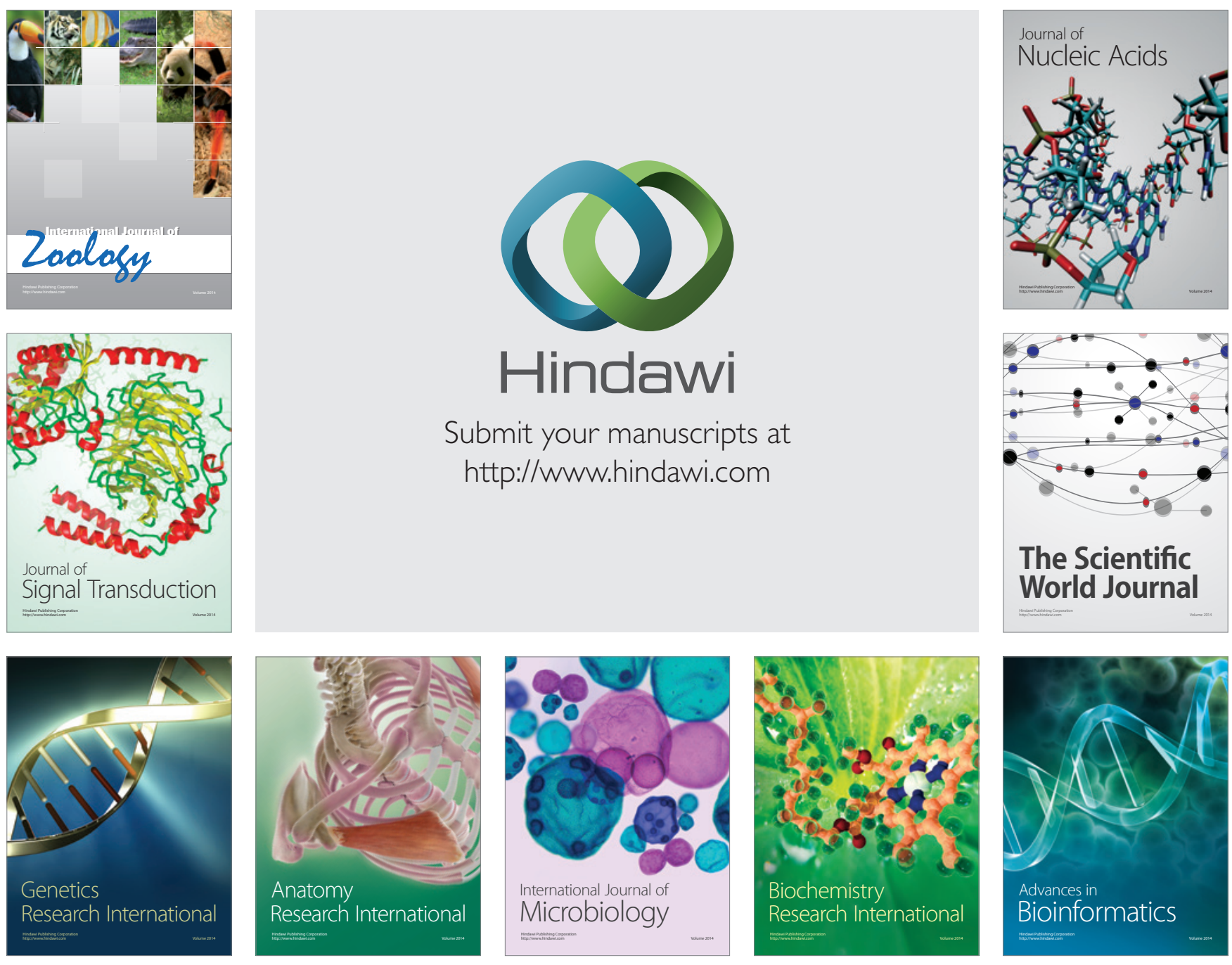

The Scientific World Journal
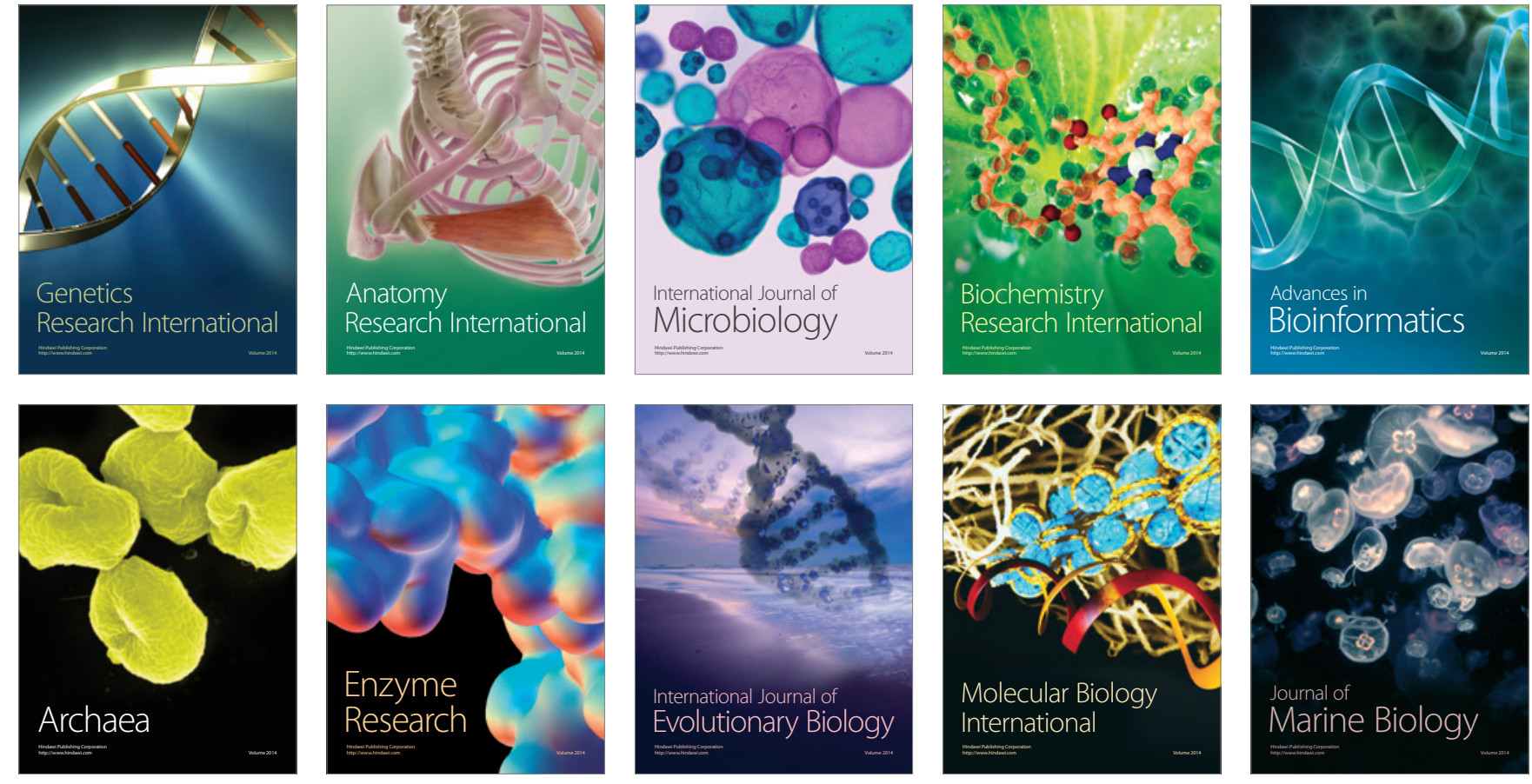